\title{
Using the Organic and Bio-fertilizers as a Partial Substitute for Mineral-N in Williams Banana Orchards
}

\author{
Abdel-Hafiz, G.; H.A. Abdel-Galil; Kamelia I.A. Amin and R.A. Ibrahim \\ Pomology Dept., Fac. Agric., Assiut University, Assiut, Egypt.
}

Received on: 6/3/2016

Accepted for publication on: 24/3/2016

\begin{abstract}
This study was carried out during two consecutive seasons of 2013/2014 and 2014/2015 on the third and fourth ration of Williams banana plants. The plants are grown in a private Orchard located at Kom Ombo city, Aswan Governorate, Egypt. The compost as an organic fertilizer, enriched with EM or bio-mex was used as a partial replacement for the mineral-N fertilizer. The experiment was set up as a complete randomized block design.

The results revealed that using the recommended dose of nitrogen (RDN) via $25 \%$ as a mineral source and 25 to $50 \%$ as an organic one enriched with 50 or $25 \%$ of EM or bio-mex significantly enhanced the length and circumference of pseudostem, leaf area and total leaf area/plant as well as percentage of $\mathrm{N}, \mathrm{P}$ and $\mathrm{K}$ of leaves compared to use the RDN only as a mineral $\mathrm{N}$ fertilizer.

Also, the $\mathrm{N}$ fertilization with a combination of mineral and organic $\mathrm{N}$ sources with a bio-fertilizer significantly increased the bunch weight and hand weight consequently increased the yield/plant, as well as improved the fruit quality compared to use the RDN only as a mineral source. The promotion on such growth and fruiting traits was associated with increasing percentage of bio-form from 25 to $50 \%$. The organic fertilizer enriched with bio-mex significantly stimulated these traits more than its use with EM.

It is evident that such $\mathrm{N}$ fertilization program is very important for the banana fruit production. It improve the nutrient status, yield and fruit quality of banana plants. In addition, it minimizes the production costs and environmental pollution which could be occurred with using chemical fertilizers.
\end{abstract}

Keywords: Organic, bio-fertilization, Banana, yield, nutrient status, environmental pollution.

\section{Introduction}

Banana (Musa sp.) is the fourth largest fruit crop in the world, following grapes, citrus and apple. It plays an important role in tropical economics as cash export and as complementary food in local sets. Bananas have a great economic importance as one of the most popular fruits in Egypt for its high nutritive value, cheap source of energy i.e. high starch content vitamins and other minerals with traces of fat (Abdel-Moniem et al., 2008).
The total area of banana increased to 60090 feddan produced 1158224 tons with average of 19.28 ton/ feddan according to Statistics of Ministry of Agriculture (2013).

Williams banana is excellent performance since the large bunch with longer fingers and the excellent taste. It owing to its large size and rapid growth rate require relatively large amount of nutrients to maintain high production of good quality fruits (Saleh, 1996). So, the major problems 
facing banana growers are the high costs of excessive manufactured fertilizers needs. Besides, these chemical fertilizers are considered as air, soil and water polluting agents during their production and utilization (Abdel-Moniem et al., 2008 and Kuttimani et al., 2013).

A combination of mineral, organic and bio-fertilizers is necessary to sustain and improve crop. Fertilization is one of the important tools to improve the soil fertility and increase crop yield. Nitrogen is known to be one of the most elements for plant nutrition and development. It plays an important role as a constituent of all proteins, nucleic acids and enzymes (Nijjar, 1985 and Marschner, 1996). Nitrogen fertilization effects depend upon the nutrient status of the soil, applied amount, sources and methods of $\mathrm{N}$ application. The nitrogen fertilizer efficiency under field and surface irrigation conditions rarely exceeds $50 \%$ and it ranges between 30 and $40 \%$ (Saharawat, 1979). A principal goal of the nature farming is producing healthy fruits without the use of chemical fertilizers synthetic auxins and pesticides and without causing adverse effects on the natural environment (Verna, 1990; Dahama, 1999 and El-Salhy, 2004). Using organic fertilizers are responsible for stimulating soil fertility and biological activity, formation of natural hormones, antibiotics and B vitamins and developments of roots as well as to avoiding all forms of pollution that may result from conventional agriculture techniques. Most organic fertilizers depends on using recycled animal manure and farm residues to produce a compost (Russo and Perlyn, 1990;
Yagodin, 1990 and Dahama, 1999). Bio-fertilization are beneficial in enhancing biological activity due to its highest own from microorganism. It is responsible in suppresses of plant pathogens and diseases conservation of energy in plant, solubilization of mineral in the soil and promotion of photosynthetic efficiency and biological $\mathrm{N}$ fixation. Nitrogen fixing cyanobacteria and the effective microorganisms (EM) are used in order to improve soil fertility, fertilizer efficiency and productivity of fruit trees (Higa and Wididana, 1991; ElHaddad et al., 1993; Myint, 1999; Kannaiyan, 2002 and El-Salhy et al., 2006).

Many authors previously mentioned that adjusting the amount of $\mathrm{N}$ as well as using the suitable amount of $\mathrm{N}$ via inorganic, organic and biofertilizers sources were very beneficial in enhancing growth and fruiting of different banana cvs as compared to use mineral-N alone (Ahmed et al., 1996 and 1997; El-Shamaa, 2001; Soliman, 2001; Kamel, 2002; AbdelMonaem and Radwan, 2003; Hammam, 2003; Ahmed et al., 2003; Hammam et al., 2003; Roshdy, 2004; Gobara, 2004; El-Shenawi and Hassouna, 2004; Sayed, 2004; El-Sawy, 2005; El-Shenawi et al., 2008; Bhalerao et al., 2009; Roshdy, 2010; Badgujar et al., 2010; Barakat et al., 2011 and Kuttimani et al., 2013).

Therefore, the objective of this study was to examine the possibility of reducing mineral-N of banana orchards, as well as, to select the optimum proportion of fertilizers.

\section{Materials and Methods}

This study was carried out during two consecutive seasons of 
2013/2014 and 2014/2015 seasons on the third and fourth rations of Williams banana plants. The plants are grown in a private orchard located at Kom Ombo region, Aswan Governorate, where the soil has a clay texture with a water table depth not less than two meters deep. Analysis of the tested soil was made according to the procedures outlined by Wilde et al. (1985) and the date are shown in Table (1). The plants were spaced at $3.5 \times 3.5$ meters apart. All plants were similar in age, growth and received the recommended agricultural practices, except $\mathrm{N}$ fertilization in all sources in the orchard was carried out as usual.

Table 1. Some physical and chemical properties of the soil of the experimental site.

\begin{tabular}{|l|l|l|l|}
\hline \multicolumn{1}{|c|}{ Soil property } & \multicolumn{1}{c|}{ Value } & \multicolumn{1}{c|}{ Soil property } & \multicolumn{1}{c|}{ Value } \\
\hline Sand (\%) & 15.43 & Total N $(\%)$ & 0.16 \\
\hline Silt $(\%)$ & 33.22 & $\mathrm{NaHCO}_{3}$-extractable $\mathrm{P}(\mathrm{mg} / \mathrm{kg})$ & 21.61 \\
\hline Clay $(\%)$ & 51.35 & $\mathrm{NH}_{4} \mathrm{AOC}-$-extractable $\mathrm{K}(\mathrm{mg} / \mathrm{kg})$ & 401.33 \\
\hline Texture & Clay & DTPA extractable $\mathrm{Fe}(\mathrm{mg} / \mathrm{kg})$ & 13.19 \\
\hline CaCO $_{3}(\%)$ & 3.66 & DTPA extractable $\mathrm{Mn}(\mathrm{mg} / \mathrm{kg})$ & 15.16 \\
\hline Organic matter $(\%)$ & 1.32 & DTPA extractable $\mathrm{Zn}(\mathrm{mg} / \mathrm{kg})$ & 2.35 \\
\hline pH $(1: 1$ suspension) & 8.10 & DTPA extractable $\mathrm{Cu}(\mathrm{mg} / \mathrm{kg})$ & 2.11 \\
\hline Ece $\left(\mathrm{dS} / \mathrm{m}^{-1}\right)$ & 2.69 & & \\
\hline
\end{tabular}

The present experiment involved seven treatments as follow:

1- Application of the recommended dose of nitrogen (RDN) of 600 $\mathrm{g} / \mathrm{plant} /$ year $(1.8 \mathrm{~kg}$ ammonium nitrate/plant/year) as mineral $\mathrm{N}$ form $\left(\mathrm{T}_{1}\right)$

2- Application of the RDN as $25 \%$ mineral-N and $50 \%$ organic plus $25 \%$ bio (EM) fertilizers $\left(\mathrm{T}_{2}\right)$.

3- Application of the RDN as 25\% mineral-N and $25 \%$ organic plus $50 \%$ bio (EM) fertilizers $\left(\mathrm{T}_{3}\right)$.

4- Application of the RDN ass $25 \%$ mineral-N and $50 \%$ organic plus $25 \%$ bio (bio-mex) fertilizers $\left(\mathrm{T}_{4}\right)$.

5- Application of the RDN as 25\% mineral-N and $25 \%$ organic plus $50 \%$ bio (bio-mex) fertilizers $\left(\mathrm{T}_{5}\right)$.

6- Application of the RDN as 50\% organic and $50 \%$ bio (EM) fertilizers $\left(\mathrm{T}_{6}\right)$.

7- Application of the RDN as 50\% organic and $50 \%$ bio (bio-mex) fertilizers $\left(\mathrm{T}_{7}\right)$.
The experiment was set up as a complete randomized block design, each treatment was replicated three times, one stool per each. Nitrogen source was ammonium nitrate $(33.5 \%$ $\mathrm{N})$ and it was splitted into 14 equal batches and added twice per each month that started on April and ended on October during each season. The organic fertilizer (compost, $4.9 \% \mathrm{~N}$ ) was added once in second week of Dec. in holes $15 \mathrm{~cm}$ depth around each plant and covered with soil after the addition. Bio-mex and EM were added in two equal batches once at growth start and one month later. Bio-fertilizer was added by making digs around each plant and putting the specific amount them irrigation. Effective microorganisms (EM) as a bio-fertilizer that contains a mixed of photosynthetic and lactic acid bacteria as well as actinomyces, yeasts and fungi. Similar bio-mex has contains the previously contantes plus humic and folvic acids. 
Regular agricultural and horticultural practices which were followed in the orchard including hoeing, fertilization with $\mathrm{P}$ and $\mathrm{K}$, irrigation with Nile water as well as pathogens, pests and weed control were carried out as usual. The following measurements were taken on selected plants.

\section{1- Vegetative characteristics:}

After the emergence of the inflorescence $\left(3^{\text {rd }}\right.$ week of July for both the third and fourth ratoons), the following parameters were studies vegetative characters. Data on the vegetative characteristics included pseudostem length and its circumference diameter in $(\mathrm{cm})$, number of green leaves per plant at bunch shooting and leaf area $\left(\mathrm{m}^{2}\right)$ using the third full sized leaves according to Murry (1960) and calculated as follows:

Leaf area $\left(\mathrm{m}^{2}\right)=$ Length $\mathrm{x}$ Width $\times 0.8$

\section{2- Leaf mineral contents:}

Leaf samples were taken from the third upper leaf from the top of the plant after bunch shooting in September of each season. A sample of $10 \times 10 \mathrm{~cm}$ from the middle part of the leaf blade was used as recommended by Hewitt (1955). Samples were oven dried at $70^{\circ} \mathrm{C}$ and digested. The clear digestion was quantitatively transferred to $100 \mathrm{ml}$ volumetric flask. In this solution, the following nutrients were determined according to Wilde et al. (1995).

a) Total $\mathrm{N}$ was determined by using micro-kjeldahl method.

b) Phosphorus was determined by using Olsen method.

c) Potassium was determined by using flame photometer.

\section{3- Yield and fruit quality:}

The bunches were harvested when the fingers reached the full mature stage as well as when the top hands and fingers become roundish and turned slightly yellow according to Nolin (1985). Before artificial ripening weights of bunch and hand were recorded. Six hands were taken from the base, middle and distal end of bunch as a composite sample for different characters. The chosen hands were wrapped with newspaper and arranged in closed wooden boxes with a glass surface to achieve artificial ripening and after the fingers were ripened, the following physical and chemical characters were determined:

a) Finger weight (g) and pulp \%.

b) Percentages of total soluble solids, total and reducing sugars and total acidity (as malic acid/100 g pulp) were determined according to A.O.A.C. methods (1995).

All the obtained data were tabulated and statistically analyzed. The differences between various treatment means were compared using L.S.D. test at 5\% according to Gomez and Gomez (1984) and Mead et al. (1993).

\section{Results}

\section{1- Effect of vegetative growth and} percentage of $N, P$ and $K$ in leaves:

Data presented in Tables $(2 \&$ $3)$ show the effect of different nitrogen fertilization sources on length and circumference of pseudostem and number of green leaves/plant as well as leaf area, total leaf area/plant and percentage of $\mathrm{N}, \mathrm{P}$ and $\mathrm{K}$ in leaves of Williams banana plants during $2013 / 2014$ and $2014 / 2015$ seasons. It is obvious from the data that the results took similar trend during the 
two studied seasons. Such data show that application of the required $\mathrm{N}$ through $25 \%$ of the recommended dose of nitrogen (RDN) along with using 25 to $50 \%$ organic enriched with either effective microorganisms (EM) or bio-mex as a bio-fertilizer at 50 or $25 \%$ significantly increased such traits compared to using RDN via mineral-N fertilizer only. The promotion on such growth traits was associated with increasing percentage of bio-form from 25 to $50 \%$. Moreover, there were insignificant difference in these studied traits due to fertilize with 50 organic plus either $50 \%$ EM $\left(\mathrm{T}_{6}\right)$ or $50 \%$ bio-mex $\left(\mathrm{T}_{7}\right)$ compared to use RDN completely via mineral-N ( $T_{1}$, check treatment).

Applications of the RDN via $25 \%$ mineral-N beside bio-mex significantly stimulated the pseudostem length and its circumference, leaf area and number of green leaves as well as total leaf area/plant and N, P and $\mathrm{K}$ rather than application of mineral-N along EM. The maximum values of length and its circumference of pseudostem and leaf traits were recorded on the plants that fertilized with the required $\mathrm{N}$ via $25 \%$ mineral$\mathrm{N}$ along $25 \%$ organic plus $50 \%$ biomex as a bio-fertilizer $\left(\mathrm{T}_{5}\right)$. On other hand, the lowest values were recorded on the plants that fertilized with $100 \%$ mineral-N (check plants trees, $\mathrm{T}_{1}$ ). The recorded total leaf area/plant was $(15.78,17.37,18.68,17.81$, $\left.19.60,15.07 \& 15.52 \mathrm{~m}^{2}\right)$ and (16.91, $18.82,20.18,19.21,21.24,16.12 \&$ $16.74 \mathrm{~m}^{2}$ ) due to $100 \%$ mineral-N $\left(\mathrm{T}_{1}\right), 25 \%$ mineral-N and $50 \%$ organic plus $25 \% \mathrm{EM}\left(\mathrm{T}_{2}\right), 25 \%$ mineral-N and $25 \%$ organic plus $50 \%$ EM $\left(\mathrm{T}_{3}\right)$, $25 \%$ mineral-N and $50 \%$ organic plus
$25 \%$ bio-mex $\left(\mathrm{T}_{4}\right)$ and $25 \%$ mineral$\mathrm{N}$ and $25 \%$ organic plus $50 \%$ biomex $\left(\mathrm{T}_{5}\right), 50 \%$ organic plus $50 \% \mathrm{EM}$ ) $\left(\mathrm{T}_{6}\right)$ and $50 \%$ organic plus $50 \%$ biomex $\left(\mathrm{T}_{7}\right)$ during the two studied seasons, respectively. Then, the increment percentage attained (10.07, $18.37,12.86 \& 24.21)$ and (11.29, $19.34,13.60 \& 25.61 \%$ ) due to $\mathrm{T}_{2}$, $\mathrm{T}_{3}, \mathrm{~T}_{4}$ and $\mathrm{T}_{5}$ over the $\mathrm{T}_{1}$ (check treatments) during the two studied seasons, respectively. Therefore, fertilizing with mixed fertilization significantly increased the total leaf surface area, nutritional status and vegetative growth of plants. This clearly ensured the beneficial effect of using organic enriched with bio-fertilizers on improving growth and nutritional status of the banana plants.

\section{2- Effects on bunch weight:}

It is clear from the data in Table (4) that fertilizing of Williams banana plants by combination of mineral-N with organic and bio-form significantly increased the bunch weight and hand weight compared to use the RDN via mineral-N source only (check treatment, $\mathrm{T}_{1}$ ). The promotion in the bunch weight and hand weight was associated with increasing percentage of bio-form from 25 to $50 \%$ of RDN. Using bio-mex as biofertilizer significantly increased the bunch weight and hand weight rather than using EM. In addition, there were insignificantly difference in the bunch weight due to using $50 \%$ organic form plus either 50\% EM $\left(\mathrm{T}_{6}\right)$ or bio-mex $\left(\mathrm{T}_{7}\right)$ compared to using RDN completely via mineral-N ( $T_{1}$, check treatment). The heaviest weight of bunch and hand were recorded on the plants that fertilized by $25 \%$ mineral-N plus $25 \%$ organic and $50 \%$ 
bio-mex. The recorded bunch weight was $(25.10,26.50,29.25,26.80$, $29.90,24.65 \& 24.95 \mathrm{~kg})$ and $(25.80$, $27.10,30.10,27.40,31.15,25.70 \&$ $25.30 \mathrm{~kg}$ ) due to use $\mathrm{T}_{1}, \mathrm{~T}_{2}, \mathrm{~T}_{3}, \mathrm{~T}_{4}$, $\mathrm{T}_{5}, \mathrm{~T}_{6}$ and $\mathrm{T}_{7}$ during the two studied seasons, respectively. The increment percentage of bunch weight was attained $(5.58,16.53,6.77 \& 19.12)$ and $(5.04,16.67,6.20 \& 20.74 \%)$ due to $T_{2}$, to $T_{5}$ over $T_{1}$ during the two studied seasons, respectively. Therefore, it is clear that fertilization using mineral-N and organic plus biofertilizer have beneficial effects on the bunch weigh of Williams banana plants.

\section{3- Effects on fruit quality:}

It is evident from the data in Tables (4 and 5) that using $\mathrm{N}$ as $25 \%$ mineral plus 25 to $50 \%$ organic enriched with 50 or $25 \%$ of EM or bio-mex significantly improving fruit quality in terms of increasing finger weight, pulp \%, T.S.S.\% and sugar contents and decreasing the total acidity compared to use the recommended dose of nitrogen (RDN) via mineral-N source only. Moreover, using RDN via $50 \%$ organic-form plus either $50 \% \mathrm{EM}\left(\mathrm{T}_{6}\right)$ or bio-mex $\left(\mathrm{T}_{7}\right)$ insignificantly effect on finger weight and pulp $\%$ but it significantly in fruit chemical properties compared to using mineral-N only $\left(T_{1}\right.$, check treatment). Fertilize via $25 \%$ mineral$\mathrm{N}$ along 25 to 50 organic- $\mathrm{N}$ enriched with 50 or $25 \%$ bio-mex significantly improving the fruit quality compared to fertilize by $25 \%$ mineral-N plus 25 to $50 \%$ organic-N enriched with 50 or $25 \%$ EM. Treating the plants with the $\mathrm{RDN}$ via $25 \%$ mineral-plus $25 \%$ organic enriched with $50 \%$ bio-mex gave the highest values of fruit traits.

Table 2. Effect of nitrogen fertilization at different sources on vegetative growth of Williams banana plants during 2013/2014 and 2014/2015 seasons.

\begin{tabular}{|l|c|c|c|c|c|c|c|c|}
\hline \multirow{2}{*}{ Charact. } & \multicolumn{2}{|c|}{$\begin{array}{c}\text { Pseudostem } \\
\text { hight }(\mathbf{c m})\end{array}$} & \multicolumn{2}{c|}{$\begin{array}{c}\text { Pseudostem cir- } \\
\text { cumference }(\mathbf{c m})\end{array}$} & \multicolumn{2}{c|}{ Green leaf/plant } & \multicolumn{2}{c|}{ Leaf area $\left(\mathbf{c m}^{\mathbf{2}}\right)$} \\
\cline { 2 - 9 } Treatments & $\mathbf{2 0 1 3 / 2 0 1 4}$ & $\mathbf{2 0 1 4 / 2 0 1 5}$ & $\mathbf{2 0 1 3 / 2 0 1 4}$ & $\mathbf{2 0 1 4 / 2 0 1 5}$ & $\mathbf{2 0 1 3 / 2 0 1 4}$ & $\mathbf{2 0 1 4 / 2 0 1 5}$ & $\mathbf{2 0 1 3 / 2 0 1 4}$ & $\mathbf{2 0 1 4 / 2 0 1 5}$ \\
\hline $\mathbf{T}_{\mathbf{1}}$ & 284.8 & 288.0 & 69.3 & 70.1 & 9.8 & 10.5 & 1.61 & 1.61 \\
\hline $\mathbf{T}_{\mathbf{2}}$ & 295.8 & 296.3 & 71.8 & 72.3 & 10.4 & 11.2 & 1.67 & 1.68 \\
\hline $\mathbf{T}_{\mathbf{3}}$ & 313.3 & 311.5 & 74.0 & 74.6 & 10.8 & 11.6 & 1.73 & 1.74 \\
\hline $\mathbf{T}_{\mathbf{4}}$ & 299.3 & 301.8 & 72.3 & 73.9 & 10.6 & 11.3 & 1.68 & 1.70 \\
\hline $\mathbf{T}_{\mathbf{5}}$ & 326.3 & 327.0 & 74.6 & 76.8 & 11.2 & 12.0 & 1.75 & 1.77 \\
\hline $\mathbf{T}_{\mathbf{6}}$ & 278.8 & 280.5 & 67.7 & 69.3 & 9.6 & 10.2 & 1.57 & 1.58 \\
\hline $\mathbf{T}_{\mathbf{7}}$ & 280.0 & 281.8 & 68.0 & 68.8 & 9.7 & 10.4 & 1.60 & 1.61 \\
\hline $\mathbf{L S D} \mathbf{5 \%}$ & $\mathbf{9 . 1 6}$ & $\mathbf{8 . 4 5}$ & $\mathbf{1 . 8 6}$ & $\mathbf{2 . 1 1}$ & $\mathbf{0 . 4}$ & $\mathbf{0 . 5}$ & $\mathbf{0 . 0 5}$ & $\mathbf{0 . 0 6}$ \\
\hline
\end{tabular}

1- Application of the recommended dose of nitrogen (RDN) of $600 \mathrm{~g} / \mathrm{plant} / \mathrm{year}(1.8 \mathrm{~kg}$ ammonium nitrate/plant/year) as mineral $\mathrm{N}$ form $\left(\mathrm{T}_{1}\right)$

2- Application of the RDN as $25 \%$ mineral-N and $50 \%$ organic plus $25 \%$ bio (EM) fertilizers $\left(\mathrm{T}_{2}\right)$.

3- Application of the RDN as $25 \%$ mineral-N and $25 \%$ organic plus $50 \%$ bio (EM) fertilizers $\left(\mathrm{T}_{3}\right)$.

4- Application of the RDN ass $25 \%$ mineral-N and $50 \%$ organic plus $25 \%$ bio (bio-mex) fertilizers $\left(\mathrm{T}_{4}\right)$.

5- Application of the RDN as $25 \%$ mineral-N and $25 \%$ organic plus $50 \%$ bio (bio-mex) fertilizers $\left(\mathrm{T}_{5}\right)$.

6- Application of the RDN as $50 \%$ organic and $50 \%$ bio (EM) fertilizers $\left(\mathrm{T}_{6}\right)$.

7- Application of the RDN as $50 \%$ organic and $50 \%$ bio (bio-mex) fertilizers $\left(\mathrm{T}_{7}\right)$. 
Table 3. Effect of nitrogen fertilization at different sources on total leaf area/plant, $\mathrm{N}, \mathrm{P}$ and $\mathrm{K}(\%)$ in leaves of Williams banana plants during 2013/2014 and 2014/2015 seasons.

\begin{tabular}{|l|c|c|c|c|c|c|c|c|}
\hline \multirow{2}{*}{ Charact. } & \multicolumn{2}{c|}{$\begin{array}{c}\text { Total leaf } \\
\text { area/plant }\left(\mathbf{c m}^{\mathbf{2}}\right)\end{array}$} & \multicolumn{2}{c|}{ N (\%) } & \multicolumn{2}{c|}{ P (\%) } & \multicolumn{2}{c|}{ K (\%) } \\
\cline { 2 - 9 } Treatments & $\mathbf{2 0 1 3 / 2 0 1 4}$ & $\mathbf{2 0 1 4 / 2 0 1 5}$ & $\mathbf{2 0 1 3 / 2 0 1 4}$ & $\mathbf{2 0 1 4 / 2 0 1 5}$ & $\mathbf{2 0 1 3 / 2 0 1 4}$ & $\mathbf{2 0 1 4 / 2 0 1 5}$ & $\mathbf{2 0 1 3 / 2 0 1 4}$ & $\mathbf{2 0 1 4 / 2 0 1 5}$ \\
\hline $\mathbf{T}_{\mathbf{1}}$ & 15.78 & 16.91 & 2.44 & 2.49 & 0.209 & 0.220 & 2.86 & 2.91 \\
\hline $\mathbf{T}_{\mathbf{2}}$ & 17.37 & 18.82 & 2.58 & 2.59 & 0.227 & 0.236 & 3.01 & 3.05 \\
\hline $\mathbf{T}_{\mathbf{3}}$ & 18.68 & 20.18 & 2.63 & 2.64 & 0.231 & 0.241 & 3.09 & 3.14 \\
\hline $\mathbf{T}_{\mathbf{4}}$ & 17.81 & 19.21 & 2.60 & 2.61 & 0.225 & 0.235 & 3.02 & 3.06 \\
\hline $\mathbf{T}_{\mathbf{5}}$ & 19.60 & 21.24 & 2.69 & 2.68 & 0.234 & 0.242 & 3.12 & 3.17 \\
\hline $\mathbf{T}_{\mathbf{6}}$ & 15.07 & 16.12 & 2.40 & 2.46 & 0.210 & 0.218 & 2.82 & 2.86 \\
\hline $\mathbf{T}_{\mathbf{7}}$ & 15.52 & 16.74 & 2.42 & 2.18 & 0.213 & 0.320 & 2.85 & 2.88 \\
\hline LSD 5\% & $\mathbf{0 . 8 3}$ & $\mathbf{0 . 9 5}$ & $\mathbf{0 . 0 5}$ & $\mathbf{0 . 0 4}$ & $\mathbf{0 . 0 1 3}$ & $\mathbf{0 . 0 1 1}$ & $\mathbf{0 . 1 1}$ & $\mathbf{0 . 1 3}$ \\
\hline
\end{tabular}

Table 4. Effect of nitrogen fertilization at different sources on bunch and finger properties of Williams banana during 2013/2014 and 2014/2015 seasons.

\begin{tabular}{|l|c|c|c|c|c|c|c|c|}
\hline \multirow{2}{*}{$\begin{array}{c}\text { Charact. } \\
\text { Treatments }\end{array}$} & \multicolumn{3}{c|}{ Bunch weight (kg) } & \multicolumn{2}{c|}{ Hand weight (kg) } & \multicolumn{2}{c|}{ Finger weight (g) } & \multicolumn{2}{c|}{ Pulp (\%) } \\
\cline { 2 - 9 } & $\mathbf{2 0 1 3 / 2 0 1 4}$ & $\mathbf{2 0 1 4 / 2 0 1 5}$ & $\mathbf{2 0 1 3 / 2 0 1 4}$ & $\mathbf{2 0 1 4 / 2 0 1 5}$ & $\mathbf{2 0 1 3 / 2 0 1 4}$ & $\mathbf{2 0 1 4 / 2 0 1 5}$ & $\mathbf{2 0 1 3 / 2 0 1 4}$ & $\mathbf{2 0 1 4 / 2 0 1 5}$ \\
\hline $\mathbf{T}_{\mathbf{1}}$ & 25.10 & 25.80 & 1.74 & 1.81 & 88.4 & 91.3 & 65.38 & 85.75 \\
\hline $\mathbf{T}_{\mathbf{2}}$ & 26.50 & 27.10 & 1.86 & 1.91 & 92.4 & 95.8 & 68.52 & 68.91 \\
\hline $\mathbf{T}_{\mathbf{3}}$ & 29.25 & 30.10 & 2.10 & 2.15 & 99.8 & 105.3 & 73.18 & 72.55 \\
\hline $\mathbf{T}_{\mathbf{4}}$ & 26.80 & 27.40 & 1.88 & 1.95 & 93.6 & 96.3 & 68.89 & 69.18 \\
\hline $\mathbf{T}_{\mathbf{5}}$ & 29.90 & 31.15 & 2.10 & 2.20 & 104.3 & 108.2 & 73.48 & 73.76 \\
\hline $\mathbf{T}_{\mathbf{6}}$ & 24.65 & 25.70 & 1.72 & 1.78 & 86.9 & 89.6 & 64.36 & 69.61 \\
\hline $\mathbf{T}_{\mathbf{7}}$ & 24.95 & 25.30 & 1.73 & 1.78 & 87.8 & 90.8 & 64.70 & 64.93 \\
\hline LSD 5\% & $\mathbf{1 . 0 6}$ & $\mathbf{0 . 9 1}$ & $\mathbf{0 . 0 6}$ & $\mathbf{0 . 0 8}$ & $\mathbf{3 . 7 1}$ & $\mathbf{4 . 3 4}$ & $\mathbf{1 . 8 8}$ & $\mathbf{1 . 7 3}$ \\
\hline
\end{tabular}

Table 5. Effect of nitrogen fertilization at different sources on some chemical finger properties of Williams banana during 2013/2014 and 2014/2015 seasons.

\begin{tabular}{|l|c|c|c|c|c|c|c|c|}
\hline \multirow{2}{*}{ Charact. } & \multicolumn{2}{|c|}{ T.S.S. } & \multicolumn{2}{c|}{ Reducing (\%) } & \multicolumn{2}{c|}{ Total sugar (\%) } & \multicolumn{2}{c|}{ Acidity (\%) } \\
\cline { 2 - 9 } $\begin{array}{l}\text { Treat- } \\
\text { ments }\end{array}$ & $\begin{array}{c}\mathbf{2 0 1 3 / 2 0 1} \\
\mathbf{4}\end{array}$ & $\begin{array}{c}\mathbf{2 0 1 4 / 2 0 1} \\
\mathbf{5}\end{array}$ & $\begin{array}{c}\mathbf{2 0 1 3 / 2 0 1} \\
\mathbf{4}\end{array}$ & $\begin{array}{c}\mathbf{2 0 1 4 / 2 0 1} \\
\mathbf{5}\end{array}$ & $\begin{array}{c}\mathbf{2 0 1 3 / 2 0 1} \\
\mathbf{4}\end{array}$ & $\begin{array}{c}\mathbf{2 0 1 4 / 2 0 1} \\
\mathbf{5}\end{array}$ & $\begin{array}{c}\mathbf{2 0 1 3 / 2 0 1} \\
\mathbf{4}\end{array}$ & $\begin{array}{c}\mathbf{2 0 1 4 / 2 0 1} \\
\mathbf{5}\end{array}$ \\
\hline $\mathbf{T}_{\mathbf{1}}$ & 18.8 & 19.1 & 7.28 & 7.35 & 16.70 & 16.95 & 0.35 & 0.37 \\
\hline $\mathbf{T}_{\mathbf{2}}$ & 20.1 & 20.4 & 7.75 & 7.83 & 17.93 & 18.08 & 0.31 & 0.33 \\
\hline $\mathbf{T}_{\mathbf{3}}$ & 20.6 & 21.0 & 7.90 & 7.96 & 18.36 & 18.50 & 0.30 & 0.32 \\
\hline $\mathbf{T}_{\mathbf{4}}$ & 20.2 & 20.5 & 7.70 & 7.82 & 18.02 & 18.31 & 0.31 & 0.32 \\
\hline $\mathbf{T}_{\mathbf{5}}$ & 21.0 & 21.4 & 8.10 & 7.94 & 18.73 & 18.69 & 0.29 & 0.30 \\
\hline $\mathbf{T}_{\mathbf{6}}$ & 19.8 & 20.1 & 7.56 & 7.69 & 17.60 & 17.78 & 0.32 & 0.33 \\
\hline $\mathbf{T}_{\mathbf{7}}$ & 20.1 & 20.6 & 7.68 & 7.78 & 17.88 & 12.10 & 0.31 & 0.33 \\
\hline LSD 5\% & $\mathbf{0 . 4 3}$ & $\mathbf{0 . 4 8}$ & $\mathbf{0 . 2 6}$ & $\mathbf{0 . 2 2}$ & $\mathbf{0 . 4 8}$ & $\mathbf{0 . 5 6}$ & $\mathbf{0 . 0 2}$ & $\mathbf{0 . 0 3}$ \\
\hline
\end{tabular}

The recorded finger weight was $(88.4,92.4,99.8,93.6,104.3,86.9 \&$ $87.8 \mathrm{~g})$ and $(91.3,95.8,105.3,96.3$, $108.2,89.6 \& 90.8 \mathrm{~g})$ due to $\mathrm{T}_{1}, \mathrm{~T}_{2}$, $\mathrm{T}_{3}, \mathrm{~T}_{4}, \mathrm{~T}_{5}, \mathrm{~T}_{6}$ and $\mathrm{T}_{7}$ during the two studied seasons, respectively. The corresponding $\mathrm{TSS} \%$ (18.8, 20.1, $20.6,20.2,21.0,19.9 \& 20.1 \%$ ) and $(19.1,20.4,21.0,20.5,21.4,20.1 \&$ $20.6 \%$ ) during the two studied seasons, respectively. Hence, the increment percentage of finger weight at- 
tained $(4.52,12.89,5.88 \& 17.99 \%)$ and $(4.93,15.33,5.48 \& 18.51 \%)$ due to $\mathrm{T}_{2}, \mathrm{~T}_{3}, \mathrm{~T}_{4}$ and $\mathrm{T}_{5}$ over $\mathrm{T}_{1}$ (check treatment) during the two seasons, respectively. Whereas, the increment percentage of $\mathrm{TSS} \%$ was attained $(6.91,9.57,7.45,11.17,5.85$ \& $6.91 \%)$ and $(6.81,9.94,7.33,12.04$, $5.24 \& 7.85 \%$ ) due to $\mathrm{T}_{2}$ to $\mathrm{T}_{6} \mathrm{com}-$ pared to $T_{1}$ (check treatment) during the two studied seasons, respectively.

Hence, the cost wise evaluation of the application of these $\mathrm{N}$ sources is in favour of three forms $25 \%$ mineral plus $25 \%$ organic enriched with $50 \%$ bio whatever EM or bio-mex. Such fertilization program is very important for the production of banana fruits, since the improve of the fruit quality induce an increase in packable yield. In addition, such fertilization treatments reduce the cost of production and environmental pollution.

\section{Discussion and Conclusion 1- Discussion}

Fertilization of nitrogen is considered an important and limiting factor for growth and productivity of different banana plants. Bananas owing to its large size and rapid growth rate require relatively large amounts of nitrogen to get high yield with good fruit quality (Nijjar, 1985). Pollution is one of the most problems that affect human health especially when the edible part of the plant is polluted with any of the pollutants. Using mineral-N fertilizers cause accumulation of harmful residual substances in the pulp of the fruits.

The organic fertilization has a positive action in increasing the activity of micro flora, water holding capacity, soil structure aggregation, soil organic matter, soil humus content and the availability of most nutrients. Such stimulation on the uptake of nutrients leads to enhancing the biosynthesis of organic foods and cell division (Miller et al., 1990). Biofertilization has an important role on biological, physical and chemical soil properties, as well as, on facilitating the fixation of atmospheric N, activating the availability and uptake of the nutrients and reducing the incidence of soil born diseases, and then improving the soil fertility (Subba Rao, 1984; Kannaiyan, 2002; ElSalhy et al., 2006). In addition, the yeast strains have high content of nutrients particularly $\mathrm{N}, \mathrm{P}$ and $\mathrm{K}$, proteins, vitamin $\mathrm{B}$ and cytokinins. It was also release $\mathrm{CO}_{2}$ which improves net photosynthesis. Moreover, the importance of yeasts, as well-known produces of organic acid and their high survival rate under extreme soil conditions, in transformation of rock phosphates and insoluble carbonates leading to increases in available phosphorus, $\mathrm{Fe}$ and other micronutrients (Vassileva et al., 2000).

Continuous application of organic and bio-fertilizers is promising in the long run of banana, as sources of organic matter, essential nutrients, amino acids, natural hormones, antibiotics and vitamins. Also, improving both physical and chemical characters of soil.

Hence, it could be concluded that the fertilization using organic and bio sources effective in improving the plant vigour expressed as an increase in leaf surface expansion and its nutrient status. These findings emphasize the vital importance of these fertilization sources in order to overcome 
the losses of nutrients by leaching, volatilization and mobility of movement elements. These sources also, improve the soil fertility due to the highest values of the residual nutrients, the enhanced solubility of nutrients and the increased activity of microorganisms. In addition, the importance of such fertilization treatments is considered for the organic farming production.

The results were in agreement with those achieved by El-Shamaa (2001), Soliman (2001), Kamel (2002), Hammam et al. (2003), Ahmed et al. (2003), Gobara (2004), Sayed (2004), El-Sawy (2005), ElShenawi et al. (2008), Bhalerao et al. (2009), Roshdy (2010), Badgujar et al. (2010), Barakat et al. (2011) and Kuttimani et al. (2013). They concluded that application in either organic or bio-form along mineral-N sources was effective on improving growth vigour and nutrient status of banana plants in favour of improving the fruiting.

\section{2- Conclusion}

Therefore, it could be concluded that using three fertilization sources improve the plant nutrients status, yield and fruit quality leading to an increase in the packable yield. In addition, it minimizes the production costs and environmental pollution which could be occurred by excess of chemical fertilizers.

These advantages will eventually enable growers to obtain high yield with good fruit quality. Furthermore, using organic and bio-fertilization sources improve the soil fertility and reduce the added fertilizer requirements. Thus, the growers are able to produce organic farming products.

\section{References}

Abdel-Monaem-Eman, A. and S.M.A. Radwan (2003). Response of Williams banana plants to bio-fertilization in relation to growth, productivity and fruit quality. Arab Univ. J. Agric. Sci., Ain Shams Univ., Cairo, 11 (2): 751-763.

Abdel-Monem-Eman, A.; A.S.E. Abd-Allah and M.A. Ahmed (2008). The combined effect of some organic manures, mineral $\mathrm{N}$ fertilizers and Algal cells extract on yield and fruit quality of Williams Banana plants. American Eurasian J. Agric. \& Environ. Sci. 4 (4): 417-426.

Ahmed, F.F.; A.S. Abdalla and M.T.Y. Sabour-Asmaa (2003). Growth and fruiting of Williams banana as affected by some antioxidant and bio-fertilizer treatments. Minia J. of Agric. Res. \& Develop., 23 (1): 51-68.

Ahmed, F.F.; M.S. Hammam and M.A. Ragab (1996). Effect of varying nitrogen sources on growth and productivity of Williams Banana. $4^{\text {th }}$ Arabic Conf. for Hort. Crops, Minia, Egypt.

Ahmed, F.F.; M.S. Hammam and M. Mayaz (1997). Adjusting the appropriate times for the addition of $\mathrm{N}, \mathrm{P}$ and $\mathrm{K}$ in Williams banana. Egypt. J. of Appl. Sci. 12 (9): 307-315.

Association of Official Agricultural Chemists (1995). Official Methods of Analysis (A.O.A.C) $14^{\text {th }}$ Ed, Benjamin Franklin Station, Washington, D.C, U.S.A. pp: 490-510.

Badgujar, C.D.; C.V. Pajari and N.M. Patil (2010). Evaluation of ba- 
nana cultivars under different fertilizer regimes. Asian J. Hort., 4 (2): 332-335.

Barakat, M.R.; S. El-Kosary and M.H. Abdl-Nafea (2011). Enhancing Williams banana cropping by using some organic fertilization treatments. J. Horti. Sci. \& Ornamental Plants, 3 (1): 29-37.

Bhalerao, N.M.; N.M. Patil; C.D. Badgujar and D.R. Patil (2009). Studies on integrated nutrient management for tissue cultured Grand Naine banana. Indian J. Agric. Res., 43 (2): 107-112.

Dahama, A.K. (1999). Organic farming for sustainable agriculture. Agro Botanic, Daryagun, New Delhi, India, pp: 258.

El-Haddad, M.E., Y.Z. Ishac and M.L. Mostafa (1993). The role of biofertilizers in reducing agricultural costs, decreasing environmental pollution and raising crop yield. Arab Univ. J. of Agric. Sci. Ain Shams Univ. Cairo, 1(1): 147-195.

El-Salhy, A.M. (2004). Organic farming in grapes production. The $2^{\text {nd }}$ Int. Conf. of Develop. And the Env. In the Arab world. Pp. 393-407.

El-Salhy, A.M.; H.M. Mazrouk and M.M. El-Akkad (2006). Biofertilization and elemental sulphur effects on growth and fruiting of King's Ruby and Roomy grapevines. Egyptian J. of Horti., 33: 29-44.

El-Sawy, Y.A.E. (2005). Studies on the effect of some organic fertilizers, ammonium nitrate and the bio-fertilizer (Algae extract) on growth and productivity of
Williams banana (Musa Cavendishii L.). M.Sc. Thesis, Fac. of Agric., Minia Univ., Egypt.

El-Shamaa, M.S. (2001). Effect of bio-fertilizers on growth and yield of banana plants (Williams cv.). Assiut J. of Agric. Sci., 32 (1): 157-166.

El-Shenawi, M.R. and M.G. Hassouna (2004). Impact of biofertilizer on growth and yield of banana Williams in the sandy soil at Nubaria region. J. Agric. Sci. Mansoura Univ., 29 (11): 6527-6535.

El-Shenawi, M.R.; S.H. Aly-Hoda and M.A.F. Badran (2008). Response of "Grandnaine" banana to humic acid, potassium and magnesium fertilization. Alex. Sci. J. 29 (4): 244-251.

Gobara, A.A. (2004). Performance of Grand Naine banana plants to biofertilization. J. Agric. Sci. Mansoura Univ., 29 (9): 52215229.

Gomez, K.A. and Gomez, A.A. (1984): Statistical Procedures for Agriculture Researches ( $2^{\text {nd }}$ ed.) Published by John Wiley and Sons, New York, U.S.A. p. 10-20.

Hammam, M.S. (2003). Effect of biofertilization on growth and fruiting of Cavendish and Williams bananas. Egypt. J. Hort., 30 (12): $67-81$.

Hammam, M.S.; E.G. Ibrahim and A.E.M. Mansour (2003). Response of William banana to some organic nitrogen fertilizers. Egypt. J. Hort., 30 (1-2): 51-65. 
Hewitt, C.W. (1955). Leaf analysis as a guide to the nutrition of banana. En. P. J. Exp. Agric., 23: 11. Higa, Y. and G.N. Wididana (1991). Changes in the soil micro flora induced by effective microorganisms. Proc. of $1^{\text {st }}$ Inter. Conf. of Kyusei Nature Farming M.S. Dept. of Agric., Washington, D.C. U.S.A., pp. 153-162.

Kamel, M.K. (2002). Physiological studies biofertilization of banana plants cv. Williams. Ph.D. Thesis, Fac. of Agric., Minia Univ., Egypt.

Kannaiyan, S. (2002). Biotechnology of biofertilizers Alpha Sci. Inter Ltd. P.O. Box 4067 Pang Bourne R. 68. M.K. pp: 1-275.

Kuttimani, R.; K. Velayudham and E. Somasundaram (2013). Growth and yield parameters and nutrient uptake of banana as influenced by integrated nutrient management practices. Inter. J. of Recent Scientific Res., 4 (5): 680-686.

Marschner, H.C. (1996). Mineral nutrition of higher plant. Academic Press Limited Text Book, $2^{\text {nd }}$ Ed. 868.

Mead, R., R.N. Currnow and A.M. Harted (1993). Statistical Methods in Agricultural Biology. $2^{\text {nd }}$ Ed. Chapman \& Hall, London, pp: 54-60.

Miller, E.W., D.L. Donahue and J.U. Miller (1990): Soils "An Introduction to soils and plant Growth" (5th ed.). Prentice Hall, International Inc. Engleword Cliffs, New Jersy, pp 303339.

Murry, D.B. (1960). The effect of deficient of major nutrients growth and leaf analysis of the banana trop. Agric. Trin., 37: 97-106.

Myint, C.C. (1999). EM nature Farming Technology, Res. and Extension activities in Myanmar. $6^{\text {th }}$ Inter. Conf. on Kyusei Nature Farming, Pretoria South Africa, 28-30 Oct.

Nijar, G.S. (1985): Nutrition of fruit trees Mrs. Usha Raj Kumar for Kalyanin publishers, New Delhi, p. 10-52.

Nolin, J. (1985). Stage of maturity of banana (cv. Giant Cavendish) at harvest a new measuring method. Fruits, 40 (10): 623-631.

Roshdy, K.A. (2010): Effect of organic and bio-fertilization as a partial substitute for inorganic fertilization on fruiting of Grandnaine banana plants.

Roshdy, Kh.A. (2004). Effect of some organic nitrogen fertilizers on growth and fruiting of Williams banana. Ph.D. Thesis, Fac. of Agric., Minia Univ., Egypt.

Russo, R.O. and G.P. Berlyn (1990). The use of organic, bio stimulants to help low input sustainable agriculture. J. of Sust. Agric., 1 (2): 19-42.

Sahrawat, K.L. (1979). Nitrogen losses in rice soils. Fert. News, 24: 38-48.

Saleh, M.M.S. (1996). Effect of fertilization with different forms of nitrogen fertilizers on growth, flowering, mineral content and yield of banana. Ph.D. Thesis, Fac. Agric., Ain Shams Univ., Cairo, Egypt.

Sayed, M.A. (2004). Influence of plant density and some fertilizer treatments on growth, yield and 
quality of Williams and Grande Naine bananas. Ph.D. Thesis, Fac. of Agric., Minia Univ., Egypt.

Soliman, M.G.A. (2001). Response of banana and guava plants to some biological and mineral fertilizers. M.Sc. Thesis, Fac. of Agric., Alex. Univ., Egypt.

Subba-Rao, N.S. (1984). Biofertilizers in Agriculture. Oxford, IBH, Company, New Delhi, p. 1186.

Vassileva, M.; R. Azcon; J. Borea and N. Vassilev (2000). Rock phosphate solubilization by free and encapsulated cells of Yaro- wia lipolytica. Process Biochemistry, 35: 693-697.

Verna, L.N. (1990). Role of biotechnology in supplying plant nutrients in the vineties. Fertilizer News 35: 87-97.

Wilde, S.A.; R.R. Corg; J.B. Lyer and G.K. Voigt (1985): Soils and Plant Analysis for Tree Culture. Oxford IBH, New Delhi, India. pp. 94-105.

Yagodin, B.A. (1990). Agriculture Chemistry. Mir Publishers Moscow, p. 278-281.

Yearly of Statistics and Agricultural Economic Dept. Ministry of Agric. and Reclamation, Egypt (2013). 
استخذام الأسمدة العضوية والحيوية كبديل جزئي للأسمدة الآزوتية المعدنية في بساتين الموز وليامز

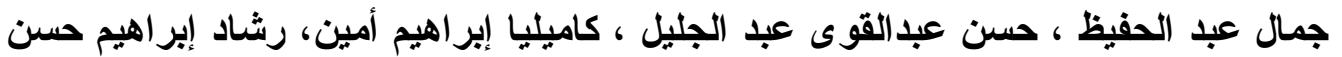

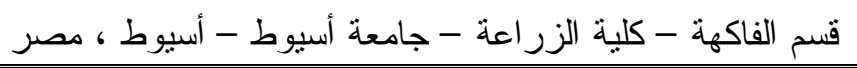

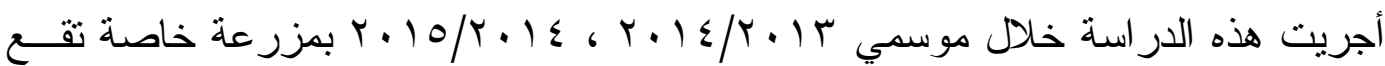

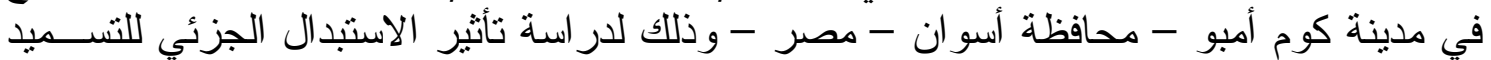

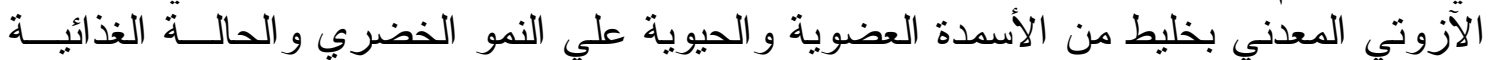

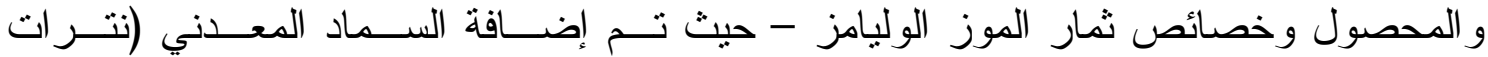

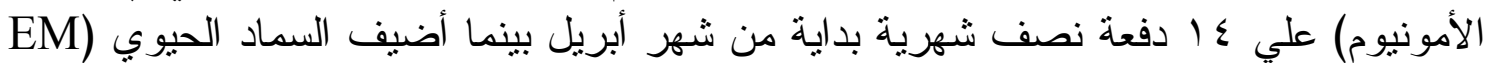

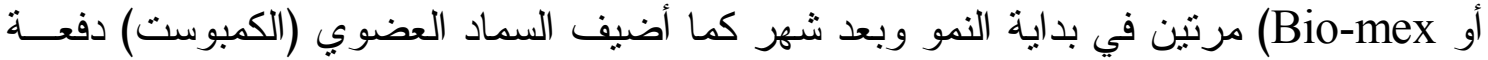
و احدة في منتصف ديسمبر . وقد أوضحت النتائج الآتي:

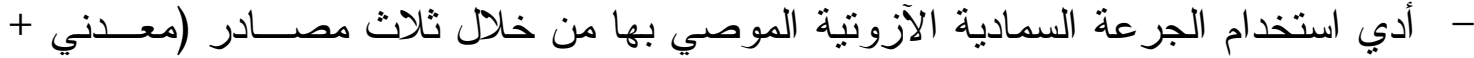

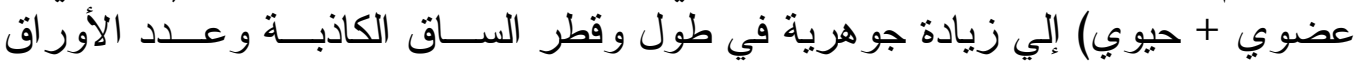



الجر عة السمادية علي صورة معدنية فقط.






السماد المعدني فقط.




- أدي استخدام السماد الحيوي Bio-mex إلي نتائج أفضل مقارنة باستخدام الســماد الحيــوي .EM







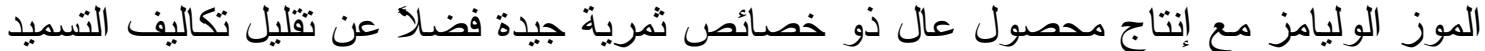
و التلوث الناشئ عن زيادة استخدام الأسمدة المعدنية و إمكانية إنتاج ثمار موز عضدية عنوية. 